\section{Surveys of Town Planning}

A BROADSHEET recently issued by Political and Economic Planning (P E P) reviews the report of the National Survey and National Planning Committee of the Town Planning Institute, the first really thorough and informed analysis of the reasons for the wasteful and undesirable development of the land which is still occurring all over England. Together with the Bressey report on the Highway Development of Greater London, it makes a major contribution to the national planning of the use of land, and as such has claims on the attention of all scientific workers who are concerned with the social problems of our technical civilization. Essentially the primary task is one of co-ordination-of fitting together the requirements of many different and often rival users of land, and where necessary choosing between them. Pointing out that there are national aspects of planning urgently requiring comprehensive study, decision and action, and that the existing planning system is quite inadequate to deal not merely with these national aspects but even effectively with the broader regional requirements, the report recommends the creation of a National Planning Commission.

THE functions of this Commission would include the compilation and collation of all relevant information bearing on the use, development and planning of land from a national point of view : advising and co-ordinating Government departments, statutory undertakers and highway authorities in their use and development of land; providing planning authorities with constructive advice and guidance, such as the Minister of Health is prevented by his quasi-judicial position from providing, watching their planning operations, and making appropriate representations to the Minister of Health when necessary. The Commission would also keep the general progress of planning under review, investigate its problems, defects and delays, frame proposals for overcoming them and generally advise the Minister and the Government on the legislative and administrative development of the planning system. As a basis for its activities and as a background for local and regional planning, it would formulate a national plan or policy on broad and flexible lines for the allocation of major land uses and developments. The wisdom of this proposal is emphasized by the revelation in the Brassey report of the widespread damage being done in the absence of such measures, and the indictment it contains of recent official policy in regard to roads.

\section{An Adolescents' Charter from Manchester}

THE Federal Council of Lancashire and Cheshire Teachers' Associations has recently issued a "Report on Entry into Employment" which includes a formulation in fourteen points of what the Council regards as "a working basis under the conditions at present prevailing in the industrial world and under the Acts dealing with school leaving and the regulation of factories and workshops now in force". Among the more significant of the fourteen points are: vocational guidance for all and, as a means for ensuring this, insistence on the submission at regular intervals by every juvenile advisory and choice-ofemployment committee of reports to the appropriate authority (in one area 23 out of $\mathbf{2 4}$ such committees were found to have ceased to function); entry into employment of a school leaver to be preceded by medical examination and report, co-ordinated in each case with the child's 'health-sheet'; all school planning to include "equipment suitable for the use of older persons, and such amenities and arrangements as will appeal to the developing mind and character of the ex-pupil" (especially in rural and detached areas); continuative education for all, and definite arrangements to induce all school leavers to continue their education, whether in technical, commercial or art schools or in less exacting or more general courses ; recreative facilities to be provided in connexion with all further education. The report dwells on the distressing waste of much of the good work done in the primary schools owing to lack of effective means for ensuring further education up to the point at which the adolescent attains to the will and capacity for self-instruction. "In the interval between leaving the primary school and the desire to proceed further, the foundation laid in the primary school has been lost since no means or care have been taken to retain it".

\section{The National Central Library}

WE read in the daily newspaper that "the lecture system has been obsolete ever since the invention of printing". Notwithstanding, the system has led at least to the demand for public libraries. The need arose from the establishment of mechanics' institutes and the foundation of lectures for adult education. Actually the public libraries movement dates from the Select Committee of 1845, which authorized a $\frac{1}{2} d$. rate for their maintenance. The corner stone of this movement is the National Central Library, unifying and binding together, as it does, the independent units of the system. The National Central Library constitutes a central bond, through which the books in any one library are made available for use in any other. The annual report for 1937 shows that, in addition to the ten million books contained in the urban and county libraries, the National Central Library has built up gradually a supplementary reservoir of another ten million books, which may be borrowed from university libraries, and those of learned societies and similar institutions.

Commencing as an experimental library for workers' educational classes at Toynbee Hall in 1914, the Library was given a Royal Charter, as recommended by the Public Libraries Committee in 1927. This report also recommended that the Science Library at South Kensington should be the principal source on which the National Central Library should rely for the loan of books needed by students of science and that the Science Library should be made as complete as possible. Thus the National Central Library has become the centre of a national library movement, with which nearly all the public, university and other libraries in Great Britain are 